\title{
APPRECIATING BY ALLOWANCE TO INCREASE MOTIVATION OF NURSES WORK IN RSUD M. SANI
}

\author{
PEMBERIAN INSENTIF DENGAN PENINGKATAN MOTIVASI KERJA PERAWAT \\ DI INSTALASI RAWAT INAP RSUD M. SANI
}

Sri Muharni ${ }^{1^{*}}$, Utari Christya Wardhani ${ }^{2}$, Muhamad Zulhan ${ }^{3}$

\begin{abstract}
Motivation with an encouraging or retrospective compensation that is regarded as what makes them work better. The purpose of this research is to know the relationship of giving incentives to the motivation work of nurses in the inpatient installation of RSUD M. SANI. This research draft is quantitative with sampling methods using Total Sampling. The samples in this study consisted of 86 nurses and data analyzed using the Spearman Rank analysis test. The results of the study showed that the number of respondents who were less incentive and good had a comparison of 43 respondents $(50 \%)$. The most number of respondents has a good work motivation of $50(58,1 \%)$. There is an incentive-granting relationship with the work motivation of nurses working in the inpatient installation of RSUD M. Sani with two variables in the Medium category ( $p$ value $=0,000$, Rho $=0,424)$. In this case the hospital is expected to be able to pay attention and increase incentives. The feasible and reasonable thing is to make clear target work conditions so that the wishes of work can increase.
\end{abstract}

Keywords: Incentive Giving, Job Motivation, Nurse

\section{INTISARI}

Motivasi dengan dorongan perspektif atau kompensasi retrospektif yang dianggap sebagai apa yang membuat mereka bekerja lebih baik. Adapun tujuan penelitian ini untuk mengetahui hubungan pemberian insentif dengan motivasi kerja perawat di Instalasi rawat inap RSUD M. Sani. Rancangan penelitian ini adalah kuantitatif dengan metode pengambilan sampel menggunakan Total Sampling. Sampel dalam penelitian ini terdiri dari 86 perawat dan data dianalisa menggunakan uji analisis Spearman Rank. Hasil penelitian menunjukkan umlah responden yang pemberian insentif kurang dan baik memiliki perbandingan jumlah yang sama yaitu 43 responden (50\%). Jumlah responden paling banyak memiliki motivasi kerja baik sebanyak 50 (58,1\%). Terdapat hubungan pemberian insentif dengan motivasi kerja

Afiliasi Penulis

1 | STIKes Awal Bros Batam

2 | STIKes Awal Bros Batam

3 | Perawat RSUD M. Sani

Korespondensi kepada

S. Muharni muharnisri@gmail.com perawat yang bekerja di instalasi rawat inap RSUD M. Sani dengan tingkat keeratan dua variabel pada kategori sedang $(p$ value $=0,000$, Rho $=0,424$ ). Dalam hal ini pihak rumah sakit diharapkan dapat memperhatikan dan meningkatkan pemberian insentif. Hal layak dan wajar yaitu membuat ketentuan target kerja yang jelas agar agar keinginan bekerja dapat meningkat.

Kata kunci: Pemberian Insentif, Motivasi Kerja, Perawat 


\section{PENDAHULUAN}

Keperawatan adalah kegiatan

pemberian asuhan kepada individu, keluarga, kelompok, atau masyarakat, baik dalam keadaan sakit maupun sehat. Pelayanan keperawatan adalah suatu bentuk pelayanan profesional yang merupakan bagian integral dari pelayanan kesehatan yang didasarkan pada ilmu dan kiat keperawatan ditujukan kepada individu, keluarga, kelompok, atau masyarakat, baik sehat maupun sakit (UU RI No. 36 Tahun 2014).

Perawat selama memberikan perawatan perlu memiliki motivasi yang tinggi dalam melaksanakan pelayanan asuhan keperawatan. Pengertian motivasi tidak terlepas dari kata kebutuhan, karena kebutuhan adalah suatu potensi dalam diri manusia yang perlu ditanggapi atau direspon. Tanggapan terhadap kebutuhan tersebut diwujudkan dalam bentuk tindakan untuk pemenuhan kebutuhan tersebut dan hasilnya adalah orang yang bersangkutan merasa atau menjadi puas (Panggeman, 2018).

Menurut Robbins dan Judge (2016) motivasi adalah proses yang ikut menentukan intensitas, arah, dan ketekunan seseorang dalam upaya untuk mencapai tujuan. Setiap pencapaian tujuan yang terpenuhi maka akan menimbulkan kebutuhan baru yang mendorong seseorang untuk bekerja lebih giat lagi. Maslow dalam Robbins dan Judge (2016) manusia memiliki lima kebutuhan yang membentuk suatu tingkatan-tingkatan atau disebut juga hirarki dari yang paling penting hingga yang tidak penting dan dari yang mudah hingga yang sulit untuk dicapai atau didapat. Motivasi manusia sangat dipengaruhi oleh kebutuhan mendasar yang perlu dipenuhi.

Penelitian Sengkey (2013) menjelaskan bahwa ada beberapa faktor-faktor pendorong motivasi yang terdiri dari motivasi intrinsik dan ekstrinsik. Motivasi intrinsik terdiri dari faktor umur, tingkat pendidikan, pekerjaan, lama bekerja, minat dan kemampuan, sedangkan motivasi ekstrinsik meliputi fasilitas, pelatihan, pembinaan, dukungan masyarakat dan insentif.

Salah satu faktor yang mempengaruhi motivasi adalah pemberian insentif, menurut Muchtar (2018) pemberian insentif bertujuan untuk meningkatkan motivasi kerja pegawai sehingga mendorong mereka untuk berprestasi lebih baik. Insentif merupakan sistem pemberian balas jasa yang dikaitkan dengan kinerja, baik bersifat materiil maupun bersifat non materiil yang dapat memberikan motivasi atau daya pendorong bagi karyawan untuk bekerja lebih baik dan bersemangat, sehingga kinerja karyawan atau hasil kerja lebih meningkat yang pada akhirnya tujuan perusahaan dapat tercapai (Rochmat et al,2013).

Menurut Nafrizal et al (2012), insentif merupakan rangsangan yang diberikan kepada karyawan dengan tujuan untuk mendorong karyawan dalam bertindak dan berbuat sesuatu untuk tujuan perusahaan. Tujuan insentif adalah untuk meningkatkan motivasi kerja karyawan sehingga karyawan bergairah dalam bekerja dalam upaya pencapaian tujuan perusahaan. Insentif merupakan pendorong individu tanpa memperdulikan bentuk insentif sebagai peran aktif dalam mendorong kemampuan individu maju dan kemampuan bergerak, memotivasi mereka untuk mereka mengembangkan ketrampilan dan keseimbangan antara kebutuhan organisasi dan kebutuhan individu yang meningkatkan organisasi secara efisien dan efektif (Al-Nsour, 2011).

Studi pendahuluan yang dilakukan peneliti pada tanggal 1 April 2019 peneliti melakukan survey awal dengan cara observasi dan wawancara dengan pihak rumah sakit serta sepuluh perawat pelaksana di ruang rawat inap flamboyan dan kenanga. 
Dari hasil observasi dan wawancara didapatkan hasil bahwa empat perawat menyatakan termotivasi karena alasan tugas atau kewajiban sebagai perawat dan enam perawat lainnya kurang termotivasi, dengan alasan tinggi rendahnya motivasi yang ada karena perawat menerima gaji yang sama, merasa kurang puas dengan hasil kerjanya dan kemampuan yang dimiliki.Hasil wawancara juga memberikan informasi bahwa kurangnya motivasi kerja dan sistem insentif yang ada masih rendah sehingga menyebabkan kinerja perawat tidak maksimal dalam melakukan pelayanan kepada masyarakat.

\section{METODE}

Penelitian ini menggunakan metode penelitian kuantitatif korelasional dengan pendekatan cross sectionaladapun yang diteliti adalah pemberian insentif dan motivasi kerja perawat di Ruang Rawat Inap RSUD X dan akan dilakukan pada seluruh perawat yang bekerja di Instalasi Rawat Inap. Alat untuk mengumpulkan data dalam penelitian ini menggunakan kuesioner. Adapun tujuan penelitian ini untuk mengetahui hubungan pemberian insentif dengan motivasi kerja perawat di Instansi rawat inap RSUD $X$. Metode pengambilan sampel menggunakan Total Sampling. Sampel dalam penelitian ini terdiri dari 86 perawat yang bekerja di instalasi rawat inap RSUD $X$ dan data dianalisa menggunakan uji analisis Spearman Rank.

\section{HASIL DAN PEMBAHASAN}

Hasil analisis berdasarkan hasil penelitian terhadap 86 responden dan dapat dilihat pada uraian, sebagai berikut:

Tabel 1 | Distribusi Responden Berdasarkan Pemberian Insentif

\begin{tabular}{lcc}
\hline \multicolumn{1}{c}{ Pemberian Insentif } & Frekuensi (f) & Persentase (\%) \\
\hline Pemberian Insentif Kurang & 43 & 50 \\
\hline Pemberian Insentif Baik & 43 & 50 \\
\hline Total & 86 & 100 \\
\hline
\end{tabular}

Berdasarkan data diatas, dapat diketahui bahwa pemberian insentif yang kurang dan baik memiliki perbandingan jumlah yang sama yaitu 43 (50\%). Insentif merupakan salah satu bentuk rangsangan atau motivasi yang sengaja diberikan kepada karyawan untuk mendorong semangat kerja karyawan supaya bekerja lebih produktif dan meningkatkan prestasinya dalam mencapai tujuan perusahaan. Pada dasarnya insentif yang diberikan kepada karyawan atas hasil kerja mereka dan biasanya diberikan dalam bentuk uang berupa bonus, komisi, pembagian laba, pemberian rumah dinas, tunjangan lembur dan tunjangan lainnya (Subianto, 2016).
Penelitian diatas sejalan dengan penelitian yang dilakukan oleh Soriton, dkk (2016) menyebutkan bahwa gaji atau upah merupakan suatu hal yang dapat meningkatkan motivasi kerja pada perawat. Insentif merupakan pengakuan dan penghargaan manajemen terhadap karyawan.

Menurut peneliti terdapat perbandingan yang berimbang antara pemberian insentif kurang dan pemberian insentif baik dikarenakan perawat yang berkerja merasa bahwa kurangnya insentif yang mereka terima dibandingan dengan profesi lain seperti apoteker dan dokter insentif yang mereka terima lebih besar padahal perawat 
yang langsung berhubungan dengan pasien juga terdapat responden yang pemberian insentif baik dikarenakan terdapat perawat yang belum lama bekerja di RSUD $X$ sehingga dengan insentif yang diterima mereka mereka merasa cukup.

Tabel 2 | Distribisi Responden Berdasarkan Motivasi Kerja

\begin{tabular}{ccc}
\hline Motivasi Kerja & Frekuensi (f) & Persentase (\%) \\
\hline Motivasi Kerja Kurang & 36 & 41,9 \\
\hline Motivasi Kerja Baik & 50 & 58,1 \\
\hline Total & $\mathbf{8 6}$ & $\mathbf{1 0 0}$ \\
\hline
\end{tabular}

Berdasarakan data di atas, dapat diketahui bahwa perawat dengan motivasi yang kurang sebanyak $36 \quad(41,9 \%)$ sedangkan pada perawat dengan motivasi kerja baik sebanyak 50 (58,1\%). Sunyoto, (2013), berpendapat motivasi adalah cara mendorong semangat kerja seseorang, agar mau bekerja dengan guna mencapai tujuan organisasi. Konsep motivasi dalam berbagai literature seringkali ditekankan pada rangsangan yang muncul dari seseorang baik daridalam (motivasi intrinsik), maupun dari luar (motivasi ekstrinsik).

Dari hasil penelitian dapat terlihat bahwa sebagian besar motivasi kerja perawat adalah baik dikarenakan perawat yang bekerja menunjukkan profesionalitasnya meskipun banyak faktor yang mempengaruhi motivasi. Perawat berusaha menujukan kinerja yang baik, dengan memberikan pelayanan yang terbaik kepada pasien, menjaga kerjasama yang baik dengan sesama perawat, perawat memiliki kemampuan untuk bertindak sesuai dengan nilai, norma dan etika di lingkungan kerja, perawat mempunyai kemauan dan kemampuan untuk menyelaraskan sikap dan tindakan sebagai perawat untuk mewujudkan tujuan pelayanan yang optimal.

Tabel 3 | Hasil Analisis Tabel Silang Pemberian Insentif Dengan Motivasi Kerja

\begin{tabular}{lcccccc}
\hline \multirow{2}{*}{ Pemberian Insentif } & \multicolumn{3}{c}{ Motivasi Kerja } & \multicolumn{2}{c}{ Total } \\
\cline { 2 - 6 } & $\mathrm{n}$ & $\%$ & $\mathrm{n}$ & $\%$ & $\mathrm{n}$ & $\%$ \\
\hline Kurang & 27 & 31,4 & 16 & 18,6 & 43 & 50 \\
\hline Baik & 9 & 10,5 & 34 & 39,5 & 43 & 50 \\
\hline Total & 36 & 41,9 & 50 & 58,1 & 86 & 100 \\
\hline & \multicolumn{3}{l}{ Rho $=\mathbf{0 , 4 2 4 ^ { * * }}, \boldsymbol{p}$ value $=\mathbf{0 , 0 0 0}$} \\
\hline
\end{tabular}

Berdasarkan data di atas, dapat diketahui bahwa responden dengan pemberian insentif yang kurang yang memiliki motivasi kerja yang kurang sebanyak 27 $(31,4 \%)$ sedangkan responden yang memiliki pemberian insentif baik yang memiliki motivasi kerja yang baik 34 (39,5\%). Dari hasil uji analisis menggunakan Rank Spearman didapatkan nilai $p$ value sebesar
0,000 yang berarti terdapat hubungan pemberian insentif dengan motivasi kerja perawat yang bekerja di instalasi rawat inap RSUD M. Sani. Berdasarkan hasil juga didapatkan nilai $R$ ho sebesar 0,424 yang 
berarti tingkat keeratan dua variabel dalam ketegori sedang.

Hasil penelitian sejalan dengan penelitian yang dilakukan oleh Kamariah (2015) dimana hasil hasil uji statistik dengan chi square diperoleh $\rho$ Value $=0,000$ yang berarti terdapat hubungan antara pemberian insentif dengan motivasi kerja pada perawat di Rumah Sakit Jiwa Provinsi Sulawesi Tenggara Tahun 2015. Setelah diuji keeratan hubungan dengan menggunakan koefisien phi $(R \varnothing)$, diperoleh nilai $R \varnothing=0,461$. Hal ini berarti bahwa antara pemberian insentif dengan motivasi kerja mempunyai hubungan sedang.

Hasil penelitian tersebut tidak sejalan dengan hasil penelitian yang dilakukan Nola Wardana tahun 2011 tentang hubungan pemberian insentif terhadap motivasi kerja perawat di instalasi rawat inap (IRNA) Medical RSUD Arifin Achmad Pekanbaru, hasil analisis menunjukkan bahwa dari 37 orang yang puas dengan non material insentif didominasi oleh responden yang memiliki motivasi yang tinggi yakni sekitar 23 orang $(62,2 \%)$, sama halnya dengan perawat yang tidak puas dengan non material insentif hanya 15 orang $(45,5 \%)$ yang memiliki motivasi yang rendah sedangkan sisanya $(54,5 \%)$ memiliki motivasi yang tinggi. Berdasarkan hal tersebut dapat ditarik kesimpulan bahwa tidak ada perbedaan antara perawat yang puas maupun perawat yang tidak puas terhadap motivasi kerja ( $p$ $0,687>a)$, dengan kata lain tidak ada hubungan antara non material insentif terhadap motivasi kerja perawat.

Berdasarkan hasil penelitian
didapatkan responden yang memiliki pemberian insentif baik yang memiliki motivasi kerja yang baik 29 (33,7\%). Hasil penelitian sejalan dengan pendapat Dimas, (2015), yaitu insentif merupakan salah satu bentuk rangsangan atau motivasi yang sengaja diberikan kepada karyawan untuk mendorong semangat kerja karyawan agar mereka bekerja lebih produktif lagi, meningkatkan prestasinya dalam mencapai tujuan perusahaan.

Menurut Mangkunegara, (2009), insentif sangat berpengaruh pada tingkat kepuasan kerja dan motivasi kerja serta hasil kerja, dimana organisasi seharusnya menentukan tingkat upah dengan mempertimbangkan standart kehidupan normal yang akan memungkinkan pegawai bekerja dengan penuh motivasi untuk memberikan kualitas kerja yang baik bagi organisasi.Menurut peneliti motivasi seseorang bisa timbul karena adanya dorongan untuk mencapai tujuan dan selanjutnya diperkuat dengan pemberian insentif yang dapat meningkatkan kinerja perawat. Dengan adanya insentif yang adil dan merata maka tidak akan terjadi kesenjangan antara profesi sehingga kinerja akan semakin meningkat dan motivasi akan berada pada level yang baik.

\section{KESIMPULAN}

Jumlah responden yang pemberian
insentif kurang dan baik memiliki
perbandingan jumlah yang sama yaitu 43
responden $(50 \%)$. Jumlah responden dengan
motivasi yang kurang sebanyak $36(41,9 \%)$
sedangkan pada perawat dengan motivasi
kerja baik sebanyak 50 (58,1\%).

\section{BIBLIOGRAFI}

Al-Nsour, Marwan. (2012). Relationship between incentives and organizational performance for employees in the Jordanian Universities. International Journal of Business and Management, 7(1), 78-89

Komariah, Ramadhona, dan Silviyanti. (2015). Improving Reading Comprehensi 
through Reciprocal Teaching Method. Jurnal Pendidikan Bahasa Inggris Universitas Syiah Kuala, (Terjemahan), Vol.2, No.2, 111

Mangkunegara, A. A. (2009). Evaluasi Kinerja Sumber Daya Manusia. Refika Aditama. Bandung

Nafrizal, Et Al, (2012), Pengaruh Insentif, Motivasi Kerja, Gaya Kepemimpinan Dan Budaya Organisasi Terhadap Kepuasan Kerja Serta Dampak Terhadap Kinerja, Jurnal Manajemen, ISSN 2302-0199, pp 52-67

Robbins, Stephen P \& Judge, Timothy A. (2016). Organizational Behavior Edition 15. New Jersey: Pearson Education

Pangemanan. Wenda R, Bidjuni. Hendro, Kallo Vandri (2018) Gambaran Motivasi Perawat Dalam Melakukan Asuhan Keperawatan Di Rumah Sakit Bhayangkara

Manado. Program Studi IImu Keperawatan Fakultas Kedokteran. Universitas Sam Ratulangi Manad, e-journal Keperawatan (e-Kp) Volume 7 Nomor 1, Februari 2019 Sengkey, G.G. (2013). Pengaruh Penerapan Sistem Pengukuran Kinerja Dan Sistem Penghargaan Terhadap Kinerja Karyawan Di PT. Bank Sulut Cabang Amurang. Universitas Sam Ratulangi Manado. ISSN 2303-1174. Jurnal EMBA 1509 Vol.1 No.4 Desember 2013, Hal. 1509-1519

Marianus Subianto, (2016). "Pengaruh Gaji Dan Insentif Terhadap Kinerja Karyawan Pada Pt. Serba Mulia Auto Di Kabupaten Kutai Barat". Jurnal Administrasi Bisnis, Vol.4 No. 3, h. 699.

Sunyoto, Danang. (2012). Manajemen Sumber Daya Manusia. Center for Academic Publishing Service. Yogyakarta.

Undang-Undang Republik Indonesia Nomor 36 Tahun 2014 Tentang Tenaga Kesehatan. 